\title{
Understanding Universities in Ontario, Canada: An Industry Analysis Using Porter's Five Forces Framework
}

James Pringle

Ryerson University

Jeroen Huisman

University of Bath

\begin{abstract}
In analyses of higher education systems, many models and frameworks are based on governance, steering, or coordination models. Although much can be gained by such analyses, we argue that the language used in the present-day policy documents (knowledge economy, competitive position, etc.) calls for an analysis of higher education as an industry. In this paper, the university sector in Ontario's higher education industry is analyzed by applying Michael Porter's five forces framework defined by the following forces: the threat of new entrants, supplier power, buyer power, the threat of substitutes, and industry rivalry. Our assessment revealed that competition in Ontario's higher education industry (university sector) is currently mixed. The findings suggest that policy-makers, the sector, and individual institutions will need to consider more seriously the impact of technology and globalization when seeking a competitive position for the Ontarian higher education system.
\end{abstract}

\section{RÉSUMÉ}

En termes d'analyse des systèmes d'enseignement supérieur, de nombreux modèles et cadres de référence sont fondés sur des modèles de gouvernance, de pilotage ou de coordination. Malgré la pertinence de ces analyses, nous soutenons que la langue utilisée dans les documents de politique actuels 
(économie du savoir, position concurrentielle, etc.), notamment, incite à une analyse de l'enseignement supérieur en tant qu'industrie. L'article revoit le secteur universitaire de l'industrie de l'enseignement supérieur de l'Ontario en appliquant le modèle des cinq formes de Michael Porter, définies en fonction des forces suivantes : la menace d'entrants potentiels, le pouvoir de négociation des fournisseurs, le pouvoir de négociation des clients, la menace des produits de substitution et l'intensité de la concurrence intrasectorielle. Notre évaluation a révélé que la concurrence au sein de l'industrie de l'enseignement supérieur en Ontario (secteur universitaire) est présentement mixte. Les résultats suggèrent que les décideurs politiques, le secteur et les institutions individuelles devront prendre en compte plus sérieusement les répercussions de la technologie et de la mondialisation pour positionner de manière concurrentielle le système d'enseignement supérieur de l'Ontario.

\section{INTRODUCTION}

In February 2005, the Honourable Bob Rae released his report Ontario, A Leader in Learning. The report was commissioned by Ontario premier Dalton McGuinty to review the design and funding of post-secondary education in the province of Ontario in five key areas: accessibility, quality, system design, funding, and accountability. Rae stated that government needs to create a stronger sense of purpose for higher education by establishing a "mission for Ontario as a leader in learning: great education, improved opportunities for more people to attend and a secure future for higher education" $(2005$, p. 9). Rae also made a strong argument that his recommendations to achieve this mission statement required a financial commitment by government at both the provincial and the federal levels.

As a result of the Rae report, the Ontario government recently committed to increase funding for the pursuit of higher education as a means to ensure students have the opportunity to reach their full potential, and to make Ontario more competitive in a knowledge-based economy. However, under current economic conditions, as the government struggles to balance its budget, these funds are unlikely to be provided in the near future (Usher \& Dunn, 2009). As institutions of higher education struggle to meet growing demands with increasingly fewer public funds, Canada and the rest of the world are feeling increased competition for alternative funding arrangements (Dill, 2003; Jongbloed, 2003; Usher \& Dunn, 2009). In addition, the shift to greater privatization of higher education is resulting in a growing trend for accountability and, concurrently, for governments to demand value for money spent (Huisman \& Currie, 2004).

Whereas policy slogans like "reaching full potential" and "being more competitive" are easily uttered, it is striking that a clear and encompassing analysis of the current competitive landscape for higher education in Ontario is lacking. To be sure, the Rae report was an ambitious and multifaceted public engagement and stakeholder consultation analysis involving dialogue through online websites, 
discussion papers, and consultative meetings; however, an overarching framework and system analysis cannot be found in the current policy debate. The key focal points of such an analysis should be: What are the strengths and weaknesses of the current system, and where and how can universities position themselves to be more competitive in the future?

\section{METHODOLOGY}

This paper will examine the higher education system in the province of Ontario, Canada, with a focus on universities, through the theoretical application of Porter's "five forces" framework. The goal is to gain a foundational perspective on the competitive landscape, its environment, its organizations, and the groups and individuals that make up the university sector in Ontario. Understanding the industry's structure is essential for effective strategic positioning so that institutions can defend themselves against competitive forces and shape them in their own favour (Porter, 2008, p. 81). Gaining such a perspective sets the groundwork for further analysis of individual institutions with respect to their particular value-chain advantage and strategically attractive competitive position. This paper is intended as a discussion piece to lead and give legitimacy to more formalized research in this area. The lead author, James Pringle, was the past program manager, and continues to maintain his role as an instructor, at Ryerson's School of Health Services Management while enrolled as a doctoral student in the Higher Education Management program of the University of Bath's School of Management. The co-author, Jeroen Huisman, is professor of Higher Education Management and the director of the International Centre for Higher Education Management (ICHEM) at the University of Bath, and is widely published in the field of higher education policy.

This study begins by explaining why Porter's five forces framework was selected for this inquiry. It will then outline the five forces defined by Porter and explore each one, with its constitutive elements, in the context of universities in Ontario. It will proceed by looking at the current policy context in, structure of, and interactions within the Ontario university system. The paper will rely heavily on existing analyses of the Canadian/Ontarian higher education system (Fisher, Rubenson, Jones, \& Shanahan, 2009; Jones, Shanahan, \& Goyan, 2004; Usher \& Dunn, 2009) and on other system analyses based on the concepts of marketization and competition (De Boer, Enders, \& Jongbloed, 2009; Duczmal, 2006; Jongbloed, 2003; Naidoo, 2005), and where those analyses are not readily available, will rely on the authors' insights. The paper will finish with some observations and recommendations for consideration by policy-makers in Ontario.

\section{ANALYTICAL FRAMEWORK}

In the higher education literature, most models and frameworks for analysis are based on defining the governance structure or steering/coordination models (e.g., Clark's Triangle of Coordination [1983], van Vught's Rational Planning and 
Control Model [1989], Olsen's Four States Model [1988], and Hood's Comparative Framework [Hood, 1998; Hood, James, Peters, \& Scott, 2004]). While much can be gained from such an analysis, the authors argue that the language used in Ontario's policy documents (knowledge economy, competitive position, etc.), in particular, calls for an analysis of higher education as an industry. In such a context the use of Michael Porter's work (2008) can be especially insightful.

\section{Porter's Five Forces Analysis}

Porter's model (1985) is grounded in microeconomics, and despite criticisms from Mintzberg (1994) and others, it is still one of the most applied strategic frameworks used today. Porter views strategy as competition and defines competition as a struggle for profits marked by five distinct forces. He argues that "industry structure drives competition and profitability, not whether an industry is emerging or mature, high tech or low tech, regulated or unregulated" (2008, p. 82). As such, the five forces define an industry's structure and shape the nature of competitive interaction within that industry (Porter, 1985).

The five forces defined by Porter are as follows. The Threat of New Entrants: New entrants to an industry bring new capacity and a desire to gain market share that puts pressure on prices, costs, and the rate of investment necessary to compete. If the barriers to entry remain high, the threat of new entrants is low. Supplier Power: If there is a limited number of suppliers for a larger number of customers with few substitutes available, then supplier power is great and the supplier can both capture the value themselves and charge premium prices. Buyer Power: Powerful customers are the flipside of powerful suppliers, and can capture more value by forcing down prices and demanding better quality or more service, thereby forcing industry suppliers to compete more aggressively against each other, usually at the expense of industry profitability. The Threat of Substitutes: A substitute product performs the same or a similar function as an industry's product by a different means. When the threat of substitution is high, industry profitability suffers, as such a threat can place a ceiling on prices. If an industry does not distance itself from substitutes through product performance, marketing, or other means, it will suffer in terms of both profitability and growth potential. Industry Rivalry: Rivalry among existing competitors takes many forms, including price discounting, new product introduction, advertising campaigns, and service improvements. High rivalry limits the profitability of an industry.

Porter (1985) has argued that the potential for a firm to be profitable is negatively associated with increased competition, lower barriers to entry, a large number of substitutes, and an increased bargaining power of customers and suppliers. Based on an analysis of these forces, Porter contended that an organization could develop a generic competitive strategy of differentiation or cost leadership that was capable of delivering superior performance through an appropriate configuration and coordination of its value-chain activities. 
Interestingly, many academics do not think of higher education as an industry and, by extension, in terms of profitability, nor do they consider the possible application of Porter's analytical frameworks. However, Naidoo (2008, p. 45) argues that "the perceptions of higher education as an industry for enhancing national competitiveness and as a lucrative service that can be sold in the global marketplace has begun to eclipse the social and cultural objectives of higher education generally encompassed in the conception of higher education as a 'public good.'" Huisman and Currie (2004, p. 533) add that increasing accountability has shifted the perception of the higher education industry from being considered a "public" or "quasi-public" good to its being considered a "private good."

\section{Applying Porter's Five Forces Model to Ontario's University System}

Several other authors have highlighted the competitive nature of higher education as the world experiences an increasing marketization of higher education (Dill, 2003; Jongbloed, 2003; Naidoo, 2005, 2008). As Dill (2003) has reported, colleges and universities compete for students, research support, faculty members, and financial contributions, and this competition is becoming both increasingly aggressive and global. Jongbloed (2003) has argued, similarly, that there are multiple markets such as those for students, research staff, lecturers, research grants, and scholarships. The underlying rationale for an open or more marketized system of higher education is that "as the number of providers grows, the competition increases and more competition leads to more efficiency, higher quality, more innovation, more differentiation and more choice for consumers" (De Boer et al., 2009 , p. 68). However, Naidoo (2008) cautions us to be wary of the consequences of the increasing pressure to marketize higher education, because the "previous integrated relationships between academics and students are likely to become dis-aggregated with each party invested with distinct, if not opposing, interests" (p. 47). Her concern is that this asymmetry may unintentionally deter innovation, promote passive learning and standardization, and further entrench academic privilege in prestigious institutions that can resist marketization-the exact opposite of what marketization and competition are celebrated as promoting.

Porter (2008) acknowledges that additional factors like the economic downturn and the rise of technology will have a direct effect on these five forces and, by extension therefore, will also have a large role to play in influencing the higher education industry as we currently know it. Therefore, these additional factors will be discussed throughout this paper in the context of the five forces. Figure 1 outlines the forces seen through the lens of higher education in Ontario, and provides the framework for the discussion below. 


\section{Figure 1.}

Higher Education Viewed Through Porter's Five Forces Framework

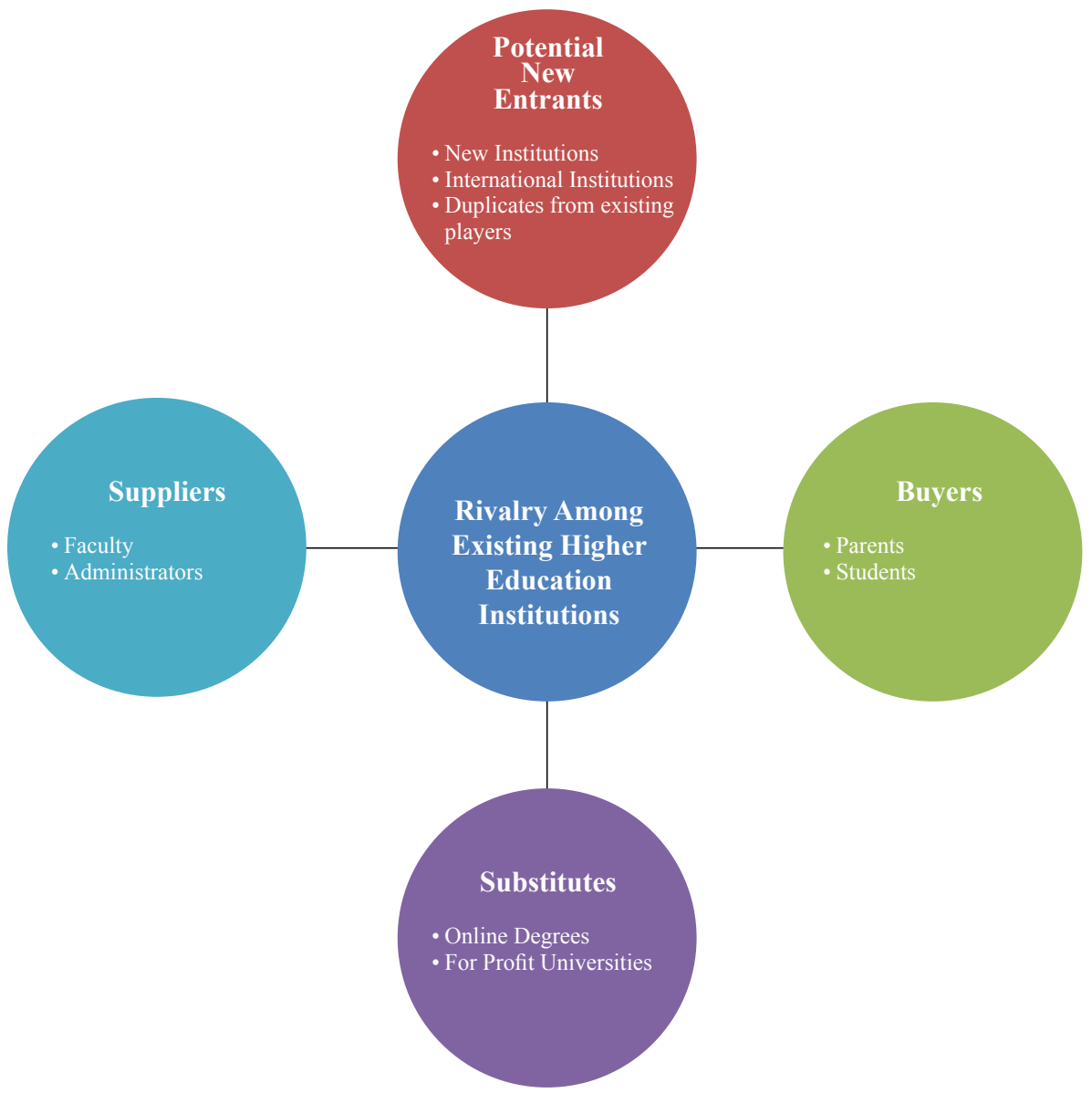

Threat of Entry

Porter (2008) describes the threat of new entrants as directly related to the barrier to entry for that particular industry. He argues that it is not necessarily the actual entry of new competitors but the threat of new entrants to the industry that drives competition and impacts the industry's profitability.

Supply-side economies of scale.

Supply-side economics maintains that production or supply is the key to economic prosperity and that consumption or demand is merely a secondary consequence. In the context of higher education this perspective would mean increasing the number of university placements (supply) available for students. Economies 
of scale refer to an institution's ability to increase productivity by decreasing the average cost per student. In the context of higher education, economies of scale imply that adding more places (increasing supply) can theoretically decrease the cost per student and, therefore, offer the same product (education) for less (tuition cost). As Martinez and Wolverton (2009) explain:

If a college offers an entry-level math course in a lecture hall that seats one-hundred students but only enrolls fifty students the college has excess capacity that it can put to use by filling the remaining fifty seats with students. There is little additional cost associated with such an action, and the college will realize economies of scale by doing so. (p. 49)

Supply-side scale economies will restrict new entrants, forcing them to enter the industry on a large scale, requiring they dislodge current higher education institutions or, alternatively, accept a cost disadvantage. That is, they would have to charge more per student (cost disadvantage) or operate under reduced profit margins until they achieve similar size and enrolments as their competitors.

\section{Demand-side benefits of scale.}

Porter (2008) explains demand-side economies of scale as network effects. These benefits arise in industries where a buyer's willingness to pay for a company's product increases with the number of other buyers who also support the company. Demand-side benefits of scale discourage entry by limiting the willingness of customers to buy from a newcomer and by reducing the price the newcomer can command until it builds up a large base of customers.

In our context, as more and more students attain university credentials, there is increasing demand (applications) for the same, because these credentials become the base expectation in the marketplace. This expectation leads to more competition for the same number of available spots, and buyers (students) are willing to pay more to capture a seat that is considered more prestigious to differentiate themselves more favourably from others with similar credentials. This situation suggests a clear advantage to the better-established institutions, as their reputation and track record provide them with the justification for charging a premium. Arguably, given government's involvement in tuition caps, the level of flexibility here is not as great as in a truly competitive, marketized environment. Nonetheless, a demand-side benefit most certainly does exist in Ontario: there are, for example, considerable fee differences for MBAs (significantly related to the prestige of the institution offering the degree).

Further, students generally wish to earn degrees from those institutions that are likely to command more respect in the marketplace: such degrees are more likely to lead to employment. For sure, newcomer institutions are unlikely to have earned a sufficient reputation and respect from industry to guarantee jobs; therefore, the demand-side benefit is not realized. In addition, to make informed deci- 
sions about institutional choices, students would require comparative information that is not always readily available. As De Boer et al. (2009) argue, demand-side conditions necessitate that consumers be free to choose the products and providers of their liking. This decision requires accurate information on a program's strengths and weaknesses and attached costs-information that is often nontransparent or comparable despite consumer perceptions to the contrary (see, for instance, the Maclean's university rankings).

\section{Customer switching cost.}

Switching costs are the fixed costs that buyers face when they change suppliers. In this context, the supplier would be the university and costs would include all activities of a university that buyers would consider, including teaching, research, and services. In the case of higher education, switching costs are affected by other factors such as location. Switching costs for students outside of the major metropolitan areas of Ontario may be considerable. Further, students often will consider location and convenience above and beyond any other cost (Martinez \& Wolverton, 2009).

Similarly, students may resist change because they have already developed strong social networks and do not wish to jeopardize their current friendships. Duczmal (2006) reports that some universities emphasize their social networks and that they differentiate themselves from other institutions by stressing the socialization process that higher education offers to its students. Interestingly, these social networks were not restricted to traditional higher education settings. Holley and Taylor (2009) studied students enrolled in a fully online bachelor of science program where students were not required to visit campus at any time during their enrolment. They found that while students did not engage in a traditional academic community practice, they experienced an expansive social network of professionals that shaped their investment and involvement in the field.

Another barrier that bears mentioning particularly in the context of Ontario universities and Canada in general is the notion of transfer credits. Duczmal (2006), speaking of the European context, argues that universities and colleges can offset students' power by raising the costs of switching from one institution to another through limiting the transfer credits available between universities, thus ensuring that once students begin degree courses they cannot readily switch to another provider. The European context is similar to the situation that prevails in Ontario.

\section{Capital requirements.}

Regardless of whether the costs are for infrastructure or technology (online providers), high capital investment as a requirement for entering an industry will reduce the threat of new entrants. In Ontario, as with the rest of Canada, budgets are shrinking and governments are increasingly less likely to fund further infrastructure costs on the backs of taxpayers. They will more likely look for increased 
efficiency and economies of scale within existing institutions. Oddly enough, the last few years of government funding for higher education in Canada and Ontario have been quite good (Usher \& Dunn, 2009). Despite a major recession, up to $\$ 2.7$ billion in federal funds have been earmarked for infrastructure projects at Canadian universities and colleges over 2010-2011. Further, because the federal government requires matching provincial funding, the actual number is closer to $\$ 5$ billion. Despite these phenomenal numbers, Usher and Dunn (2009) caution that this funding runs the risk of being absorbed into a university's general operating budget. Further, they argue, governments typically wait until a recession is over before beginning the difficult task of balancing the books, with the likely result of reductions to funding for higher education. As a consequence, new entrants looking for capital to fund infrastructure are unlikely to be able to look to government for help; thus, this aspect will remain a strong barrier to entry.

\section{Incumbency advantages independent of size.}

Established higher education institutions have a clear incumbency advantage that is not available to potential new entrants to this industry. First, they already have an established reputation and established buyers (students). Further, they have the administrative and complex scholarly (faculty) and political connections that enable them to function relatively smoothly and sustain their reputation. Knowledge, an institution's raw material, is supplied by academics who are already entrenched in established institutions and understand the players in the industry. Academics, by their nature, seek to work with others of similar interests and develop collegial relationships with those from other equally well established institutions with similar academic reputations, further perpetuating the cycle. In support of this concept, Jongbloed (2003) argues that new providers will likely face increased competition from such established providers, who, in all likelihood, will use their collective market power to protect their market share and restrict new entrants into their market.

\section{Unequal access to distribution channels.}

If we remove online education from the equation, then access to higher education is largely affected by the transportation infrastructure surrounding universities that enables students to access a university campus easily. Presumably, institutions that are located along well-established public transit routes have a competitive advantage over those with poor transit links. As a result, large, wellconnected metropolitan universities like Ryerson University, the University of Toronto, and York University have a distinct advantage over more isolated ones like Laurentian University and Nipissing University. Further, it is interesting to note that perhaps in response to this access issue, several universities have set up satellite schools along this transportation corridor. As examples, McMaster University in Hamilton has opened a campus in Burlington, and the Ivey School of Business 
of London's University of Western Ontario has a campus (the ING Leadership Centre) in downtown Toronto. In this context, the suggestion is that distribution channels remain a strong barrier for new entrants that do not have access to comprehensive public transit systems.

\section{Restrictive government policy.}

Restrictive government policy is clearly a strong barrier to entry for higher education institutions in Ontario, as the provincial government ultimately controls the number of higher education institutions. For obvious reasons, this situation is principally because the majority of institutions (about 55\%) are in large part publicly funded. Interestingly, in an effort to initiate more competition for universities, the provincial government, under the previous Progressive Conservative administration, decided to allow colleges to apply for ministerial consent to offer degrees in addition to diplomas. As a result, 72 degrees are currently offered by various colleges throughout Ontario. However, this approach appears to be much less radical than the one adopted by British Columbia, where colleges have been given increased degree-granting powers (Fisher et al., 2009, p. 555).

In summary, viewed according to Porter's competitive-force principle of Threat of Entry, the potential barriers discussed above reinforce the notion that a low entry barrier will lead to more providers and, consequently, to more competition, while a high entry barrier will lead to fewer providers and less competition. After considering several potential threats to entry, however, one can reasonably argue that the barriers to entry in Ontario would be considered to be quite high and therefore that the threat of new entrants as one of the five forces would be considered to be relatively weak.

\section{The Power of Suppliers}

According to Porter (2008), powerful suppliers capture more value for themselves by charging higher prices, limiting quality or services, or shifting costs to industry participants. Suppliers are those organizations or individuals that provide the materials, information, or knowledge to allow an organization to produce its products and services (Martinez \& Wolverton, 2009). While support services for universities like bookstores, health clinics, and food services also make up a portion of supplier power, by far the biggest contributor is highly skilled labour in the form of instructors, researchers, and administrators. In higher education, the faculty make up a significant proportion of a university's expenditures, and while non-academic staff are probably a close second, the non-academic staff traditionally do not possess the same degree of power as the academic staff. However, in the context of supplier power, this aspect is more complex and may in fact be shifting with the increasing marketization and accountability of higher education.

At most universities in Ontario, faculty do wield a great deal of power because of powerful unions and associations. However, not everyone who is considered 
part of faculty has the same degree of power. Martinez and Wolverton (2009) argue that tenured faculty have more power than those without tenure, and tenured faculty are able to exercise their power with little interference from administration with respect to both teaching and research requirements. They also argue that the amount of power may vary greatly between institutions depending on the status and reputation of the university and, by extension, the talent they recruit. Many professors at elite institutions are highly respected and considered thought leaders in their field. As such, they have even more power than their peers, because the prestige they provide their university makes them very difficult to replace. Duczmal (2006) goes further and states that without a strong academic faculty no higher education institution can be successful, because it is their academic teaching and research that defines a university and provides the legitimacy for the credentials the university confers. He also argues that everything else, such as administrative functions, laboratories, and libraries, exists simply to assist the academics in their work.

Duczmal tempers this argument by commenting on the increasing complexity of universities and the gradual erosion of academic power. He states that traditional forms of governance are being replaced by managers, who often come from commercial enterprise. This view is supported by White, who posits that "one of the widely shared fantasies is of teacher omnipotence in education" (2009, p. 138). White argues that through-put, attracting funding, and efficiency have become the key university performance indicators, and that university culture has changed, transforming education into a commodity. Rather than having authority, White claims, teachers become planners and facilitators and assume a more administrative role with students.

In Canada and the province of Ontario, the governance of higher education is traditionally dictated by a bicameral structure, with the academic senate in control of academic matters and the governing board in control of administrative matters. Jones et al. (2004) have argued that while academics have traditionally controlled a great deal of power, there has been an increased power shift to the governing board away from the academic senate. In their words:

Canadian senates have an important traditional and symbolic role, but their practical and meaningful participation in important, defining university decisions is limited and perhaps even diminishing .... It is within this context that our study raises concerns over the effectiveness of the senate and suggests a need to review its role in contemporary university governance. (p. 64)

Porter (2008) argues that supplier power is strong if (1) it is more concentrated than the industry it sells to (students), (2) industry participants (students) face switching costs in changing suppliers, (3) suppliers offer products that are differentiated, and (4) there is no substitute for what the supplier group provides. All of these would support the position that, on balance, despite some erosion in the power of the supplier, the academic faculty maintains a strong bargaining position 
and degree of power in the higher education industry. As Duczmal (2006) states, ultimately the faculty's bargaining power remains high, because currently there are no realistic substitutes. He warns, however, that this situation may change in the future with the pressure for standardization (see next section).

\section{The Power of Buyers}

In the case of higher education, the buyer is the student and his or her parents, where applicable. On the surface, it would appear that in this scenario, the buyer has less power than the supplier. Duczmal (2006) argues that this imbalance is because of an asymmetry of information, but that such asymmetry is countered by students when they are organized, as in a student union, and are represented on decision-making bodies. Arguably, when organized, previously weak stakeholders can become powerful leaders for change. Duczmal describes student reaction in Western Europe to deteriorating conditions during the rapid expansion of the 1960s, a reaction that led to significant reforms of higher education at that time.

Canada has one of the highest average post-secondary educational attainment. However, this attainment may largely reflect college diplomas rather than university degrees. In Ontario, approximately $26 \%$ of individuals aged 25-64 reported having attained a bachelor's degree or above, while $31 \%$ reported a college diploma or apprenticeship certificate (Berger, 2009). Regardless, Canada as a whole seems to have a strong cultural propensity for post-secondary educational attainment as an immediate pursuit following high school. Further, there seems to be strong public opinion in Canada at this time with regard to higher education, which the federal and provincial governments increasingly feel the need to recognize and respond to. Maclean's magazine may have been instrumental in first giving voice to public opinion with its annual report on student surveys of Canadian universities; however, most institutions now actively canvass and measure student opinion through the National Survey of Student Engagement (NSSE) report. This development signals that students as a group are now clearly considered by many to be a significant force and a strategic player in the higher education industry.

Clearly, the bargaining power of buyers is greatly influenced by perceptions formed by information available through published rankings and league tables. NSSE, Maclean's, US News and World Report, and the Financial Times all produce rankings and information that allow students and parents to compare one institution with another. Duczmal (2006) believes that the power of students increases as the services offered become more standardized, which allows them to more readily compare offerings and make more informed choices, thus lowering the switching costs. Further, accreditation, particularly for professional schools, like law, business, or health care, is also a significant factor in the perceived reputation of an institution. Graduates from accredited programs are generally perceived to be more competitively positioned in the employment market than their unaccredited competitors. Interestingly, while many perceive tuition cost as an influential 
factor in student choice, Jongbloed (2003) states there is very little evidence that a student's enrolment choice depends on the level of tuition. Unfortunately, in contrast to statements above, he also argues that there is ample evidence that students do not factor future benefits into their enrolment decisions either (p. 125).

Duczmal (2006) argues that the power of students increases with the number of options they have to choose from. In Ontario, choice is limited by provincial government restrictions on who is allowed to provide higher education services; however, as noted earlier, 72 degrees are now offered through colleges. With more and more colleges offering degrees, students and parents will have more choices and the competition for buyers will grow. Further, the growth of online substitutes from such institutions as Athabasca University and the University of Phoenix can only add to the future options available to students. As Duczmal (2006) has pointed out, the appearance of new higher education institutions erodes the monopoly that traditional institutions have had on the provision of higher education, which can limit the ability of universities and colleges to increase tuition fees.

Porter (2008) argues that powerful customers can capture more value by forcing down prices, demanding better quality or more service, and generally playing competitors off against one another. They have significant power if the industry's product is standardized and if they face few switching costs by changing vendors. As argued in the previous section, while such a dynamic may potentially operate in higher education, student power is currently muted and less significant than its counterpart, supplier power. Further, Porter argues, buyer power is reduced given many buyers do not purchase in volumes that are large relative to the size of a single vendor, as is clearly the case in the higher education industry.

Therefore, in summary, the increasing adoption of the NSSE and use of student opinion in league table rankings suggest a stronger influence or power for the buyer. In contrast, there continue to be significant switching costs in Ontario, as evidenced by criticism that the current various ranking systems lack true comparability and ongoing transfer-credit restrictions. Further, as suggested by Porter, buyer power is also reduced, because students continue to exercise the bulk of their power as individuals, while faculty as suppliers operate under an organized union. As a result, buyer power, arguably stronger than in the past, should be considered more moderate when measured in comparison to its counterpoint, supplier power.

\section{The Threat of Substitutes}

According to Porter (2008), a substitute performs the same or a similar function by a different means. When the threat of a substitute is high, industry profitability suffers. For Martinez and Wolverton (2009) the threat of substitutes is defined by three attributes: convenience, time, and application. They consider time to be the most important factor driving students to seek out substitute products, arguing that students do not want to invest four to five years to obtain a bachelor's degree, nor do professionals want to leave the workforce for two years to complete 
a traditional master's degree. As a result, many students are demanding alternatives that decrease the completion time for a degree. This demand can be viewed as an opportunity for the for-profit industry. Similarly, convenience is largely responsible for driving the adult learner to seek out alternative modes of education. As a result, in addition to the distance/online market, the delivery methods of evening, weekend, and modularized programs are increasing. Organizations that seek to respond to this group by offering convenience and decreased time may find that they become the industry standard.

It could be argued that provincial governments and universities do not yet recognize the potential threat, but Canada and Ontario may not be able to ignore private online institutions much longer. Huisman and Currie (2004), speaking about the need for accountability, argue that technology has hastened the globalization process because the location of a higher education institution is less relevant as technologies allow institutions to work globally and easily across national boundaries (p. 533). Despite quality concerns about online universities, traditional universities will need to consider how to effectively compete with online providers, because any quality concerns are likely to be rectified in the near future.

In addition, Martinez and Wolverton (2009) highlight an interesting discussion about the growing consideration of an economic rationale for seeking higher education over the traditional philosophical rationale of pursuing an education for the sake of greater knowledge and understanding of the world at large. Today's students are driven to search for training and knowledge that will lead to jobs. Likewise, governments are funding research based on an institution's ability to pursue application-based research over theory-based research. Overall, Martinez and Wolverton conclude, competitors that offer viable substitutes will combine convenience, time, and application through delivery options made possible by technology. Online universities are setting themselves up well to compete under this new rationale.

Interestingly, Duczmal (2006) argues that universities can decrease the threat of substitutes by entering substitute markets. Already we are seeing some movement in that direction, with mixed success, of universities entering the distance education market. Ryerson University, long a leader in this area, currently offers over 150 distance-format courses each academic year. However, as discussed earlier, entering the distance education market is not without risks, and some universities have been forced to close their online distance education units because of an inability to compete with entrenched online universities like the University of Phoenix (Elloumi, 2004).

The threat of substitutes may also depend solely on how one views and interprets the educational experience. If one considers the experience and socialization inherent to the traditional university experience to be of paramount importance, then the threat of substitution may be low, as the barriers to entry, such as the required facilities and supportive administrative structure, are high. If one, however, considers the Internet and the arrival of the "digital native" to be a growing force and driver for change in higher education, then the threat of substitutes is extremely high. 


\section{Rivalry Among Existing Competitors}

According to Porter (2008), rivalry among existing competitors takes many forms, including price discounting, new product introduction, advertising campaigns, and service improvements. In the higher education industry, the intensity of rivalry depends on the object of the competition: students, faculty, donors, or government-based funding and research dollars. As indicated by Martinez and Wolverton (2009), this rivalry can be defined further by examining structural factors: the profile of existing players and the industry context.

\section{Profile of existing players.}

Martinez and Wolverton (2009) report that the profile of existing higher education institutions is defined by the number and type of institutions in the pool, which will therefore determine the degree to which each institution must compete for students, faculty, government-based funding, and research dollars. In Ontario, there are 22 public universities, 17 privately funded institutions with degreegranting authority (primarily with religious affiliations), 72 degree programs offered under ministerial consent, and 24 colleges. Of the 22 public universities in Ontario, four are located in Toronto, three of which (Ryerson, Toronto, and York) would be considered comprehensive, with a large offering of similar programming. The fourth institution, the Ontario College of Art and Design, is well differentiated as a niche competitor.

In Ontario, particularly in Toronto (a densely populated metropolitan area), the higher education industry can be considered very competitive. The institutions are located on the major transit lines, and therefore service a relatively large geographical area of 5-6 million people. Each has very high application rates across the country and competes aggressively for students, faculty, and government funding. Yet while being downtown and connected to a major transit hub has its advantages by drawing more students, it also has its disadvantages. Duczmal (2006) argues that in a system with higher education institutions of roughly equal size and providing similar programs, rivalry will increase because more providers must compete for the same student segments and inputs, including faculty and funding. Despite large application numbers based on location, competition for the best students, best faculty, and more funding remains strong. Therefore, the more similar the universities are in one region, the higher the rivalry between them. One potential response identified by Porter (1985) is that organizations seeking a competitive advantage will employ one of three strategies: cost leadership, differentiation, or a focus strategy. For example, one institution may choose to differentiate its programming by offering specializations unavailable at competitor institutions or specializations for which the government will provide additional subsidies. Alternatively, if a cost leadership strategy is adopted, an MBA from one institution may be offered at a cheaper rate than at its more prestigious competitor. 
In contrast, other universities in Ontario that do not have the benefit of being linked to a comprehensive transit infrastructure are struggling with enrolments and are seeking alternative methods for attracting students by setting up satellite campuses and aggressively establishing online and distance-education degree options. Further, these typically smaller institutions located outside of larger metropolitan areas face further challenges with attracting funding and research dollars. A recent news report stated that five of Canada's largest universities have proposed that governments concentrate research and graduate studies in the biggest schools and that top research dollars should be focused on these schools (CBC News, 2009).

\section{The influence of industry context.}

Martinez and Wolverton (2009) argue that higher education is strongly influenced by political, economic, social, and technological variables. Government funding fluctuates with the economics of the time, and political attention to higher education waxes and wanes depending on the political party in power and the proximity of an election. Currently, with a Conservative federal government and a Liberal provincial government, both experiencing the effect of one of the worst recessionary periods of our times, one could argue that in a climate of fiscal restraint, the competition for other sources of funding will likely be on the rise. Further, technology is also a major influence on the intensity of rivalry, and those institutions in Ontario that have invested in using advanced technology for teaching or research have enhanced their competitive positions. These factors require some more explanation and will be discussed separately below.

\section{Government and Current Economics}

One cannot complete an industry analysis without considering the current economic situation and its impact on the five forces outlined above. As indicated by Usher and Dunn (2009), Canada's and Ontario's higher education industry is about to face some significant economic challenges. They report that, until recently, higher education institutions have experienced strong relative increases in funding when compared to student growth, government expenditures as a whole, and expenditures on health care. However, the recent economic crisis has left higher education institutions with serious budgetary challenges.

As a result of the recent economic downturn, higher education institutions in Ontario are suffering dramatic losses in their endowments. Clearly, for more established universities, endowments make up a significant proportion of their discretionary income, supporting such things as scholarships and bursaries. According to Usher and Dunn (2009), Canadian universities in 2007 collectively reported having just over $\$ 10$ billion in assets under management. Nearly a quarter of this figure was at Ontario's University of Toronto. They estimate that while global markets have fallen some $30 \%$, it is reasonable to assume that these endowments have fallen by 15 to $30 \%$. That is, approximately $\$ 2$ billion is no longer avail- 
able. Further, they argue, as governments attempt to balance their own finances, universities should also anticipate and prepare for a reduction in base funding transfers. The authors report that, similarly to other provinces in Canada, Ontario will likely delay any cutbacks on transfers to higher education until after the recession. As a result, while current transfers remain intact, one should expect that the budget cycles of 2011 and beyond will be much more restrictive and that cuts to the funding for higher education are to be anticipated.

In addition to provincial cutbacks, Usher and Dunn (2009) report, federal funding for higher education by way of research grants appears to have been affected similarly, and more quickly, with the Government of Canada eliminating or reducing funding to several research initiatives. Private sources of funding research have also felt the effect of the current recession, and this circumstance could affect the ability of higher education institutions to retain or attract talented researchers from countries that are able to provide better funding.

Finally, Usher and Dunn argue that circumstances are only likely to get worse due to demographic challenges. They stress that around the year 2014 the main cohort of baby boomers will begin to retire, with the result that the cost of elder care will continue to rise while the percentage of workers in the workforce begins to decline, adding additional stress on budgets beyond the current economic climate. The authors call this the Peak Post-Secondary Scenario, and predict that as the recession abates, societal priorities are likely to be pushed away from education by demographic pressure and lead to declining per-student provincial funding. They argue that with cuts in funding from government transfers and declining interest on endowments, tuition is the only resource left that universities can use to restore funding levels. Usher and Dunn posit that if tuition does not increase, the only alternative left for universities is to cut programs and services.

\section{TECHNOLOGY}

Porter (2001) has argued that while the Internet is an important new technology, it is no more than a complement to traditional ways of competing. However, a recent report released by the U.S. Department of Education (2009) states that students who take all or part of their classes online perform better, on average, than those taking the same course through traditional face-to-face instruction. This report supports the perception that online learning is growing and maturing and therefore becoming an effective competitor to traditional learning. It also raises questions about the validity of arguments that suggest that online courses are of lower quality when compared with traditional ones.

Christensen (1997) has argued that disruptive technologies often do not perform well initially when compared to traditional technologies and often do not appeal initially to the majority of customers. However, they bring something that a small segment of the market (the early adopters) finds sufficiently important that they are willing to sacrifice something else they value. Often traditional providers 
of the same product ignore the competition as the new entrant draws a smaller, less significant part of the market that traditionally offers less profit. As technology improves over time, however, the characteristics sought by the majority will improve sufficiently to shift the market, making the disruptive technology mainstream, and thus pushing out the traditional markets (Christensen, 1997). The only question is the degree to which this dynamic will play out in higher education.

Advances in technology have caused significant advances in the provision of online education around the world, including in Ontario. Many for-profit institutions, like the University of Phoenix, have greatly extended their existing programs, though their success in Canada has been limited with the recent closing of Meritus University. On the non-profit side, some non-traditional models such as Athabasca University and the Open University have been growing in acceptance across Ontario (and beyond). Interestingly, the most common argument in support of traditional universities has been that new technology approaches are inferior and appeal to those students whom traditional institutions have no interest in targeting, typically, the more mature student. Yet this development appears to fit nicely with what Christensen describes as disruptive innovation (Armstrong, 2006).

As with most disruptive technologies, the costs are decreasing and the economies of scale are excellent. The new online universities typically do not perform research and do not have to provide an expensive infrastructure to support student socialization. Faculty members are not typically research-oriented, and as such are less competitive and less expensive to maintain. They are also unlikely to be tenured, and therefore programs are much more flexible in terms of hiring and firing in response to student demand (Armstrong, 2006). In support of this reasoning, Huisman, De Weert, and Bartelse (2002) report that a "larger proportion of temporary personnel relative to tenured personnel would increase the adaptive power of universities toward varying external circumstances such as changing student numbers, budget cuts, and other financial variables" (p. 142). However, as indicated earlier, the challenge for online universities lies with credentialing. For those students who are seeking higher-level degrees, there is still a bias against the online, distance, or private university degree (Martinez \& Wolverton, 2009). Nevertheless, it remains a potential disruptive innovation. Over time, as the substitute product improves, it will likely be harder to make the argument that traditional education is superior to online education.

Based on the above factors, rivalry among competitors in the higher education market will continue to grow as government reduces its regulative capacity and financing. Institutions will be forced to search for new and innovative ways to fund resources that provide competitive value in the higher education industry.

\section{CONCLUSION AND DISCUSSION}

The preceding discussion has demonstrated the value of applying Porter's analysis (2008) to the higher education industry (university sector) in Ontario in 
helping us understand how the economic value created by the industry is divided: how much is retained by higher education institutions versus how much is bargained away by customers and suppliers, limited by substitutes, or constrained by potential new entrants. As posited by Porter, an awareness of the five forces can help institutions understand the structure of their industry and stake out a position that is more advantageous and less vulnerable to attacks from competitors.

This paper has sought to map out the competitive landscape of higher education in Ontario with a focus on the university sector. Porter's five forces framework helps to delineate the effects of supplier power and rivalry as powerful forces in the higher education industry that lead to tighter profit margins. In contrast, high barriers to entry reduce the threat of new entrants in the industry, lowering competition and thus raising potential profitability for higher education institutions. Perhaps the most interesting result from applying Porter's framework is that in higher education as well, the power of buyers and the threat of substitutes can potentially shift over time. Technology and governmental policies are powerful drivers of such shifts.

Regarding technology, it is interesting to note that while few details are known, in March 2010, the Ontario Government stated in its throne speech that it was investing in a fully online university, similar to Alberta's Athabasca University, called the Ontario Online Institute. Technology can quickly shift the power between supplier and buyer. For example, when airlines were able, thanks to the Internet, to sell tickets directly to customers and bypass travel agents, buyers' power to bargain down agents' commissions significantly increased (Porter, 2008, p. 89).

Speaking of governmental policies, the competitive landscape could change rapidly if Ontario chooses to restructure its higher education system to one similar to that of the province of British Columbia, which has gone much further than Ontario and blurred the roles of polytechnics, colleges, and universities to a great extent so that "degree-granting status has been granted to virtually all PSE institutions in a hierarchy of undergraduate and graduate applied and 'pure' degrees" (Fisher et al, 2009, p. 555). In that regard, Porter (2008) reminds us that industry structure is constantly undergoing modest adjustments and argues it can also change abruptly. According to Porter's theory (1985), to improve beyond the average industry profitability or to succeed in a more competitive environment, institutions will need to study their value chain and determine a competitive strategy of differentiation or cost leadership capable of delivering superior performance through an appropriate configuration and coordination of their value-chain activities. For example, they could decide to differentiate themselves by concentrating solely on undergraduate or doctoral programs or, alternatively, choose to focus on, and specialize in, only medical or health care programs or business programs. In this context, it is interesting to note that a report released in October 2010 by the Higher Education Quality Council of Ontario (HEQCO) recommended a restructuring of Ontario's university sector by adopting a differentiation strategy: "For government, greater differentiation of Ontario's university sector is one of 
the most powerful levers available, especially in times of resource constraints, to achieve public goals of greater quality, competitiveness, accountability and sustainability" (Weingarten \& Deller, 2010, p. 2).

Our analysis was at the industry level, but obviously it would be interesting to focus on individual competitive strategies of higher education institutions in Ontario. As Duczmal (2006) reminds us, a "loss of competitiveness may lead to loss of prestige, reputation, market share and, in the case of private organisations, even bankruptcy. In contrast, having a competitive advantage over other (competing) organisations brings with it sufficient student enrolments, in turn generating state funding and tuition fee income, which is necessary for further development" (p. 138).

This paper has taken a novel approach to examining a higher education system in a manner more typically reserved for business and private enterprise. However, as articulated at the beginning, higher education as an industry is facing increasing pressure toward marketization, and therefore an analytical approach more often seen in the business world is warranted. Naidoo (2005) argues that "education is likely to be reconceptualized as a commercial transaction, the lecturer as the commodity producer and the student as the consumer" (p. 29), and argues that "commodification of higher education reduces the rewards and sanctions from one based on academic prestige to competitive activities intended to generate income" (p. 32). It is this concept of generating income and profits that supports the application of frameworks like Porter's five forces analysis to higher education. However, in applying and interpreting such an analysis, Naidoo (2005, 2008) reminds us to be cautious of the effect that commodification may have on higher education, arguing that these forces may in fact make worse the things they are designed to improve, particularly equity and quality, two values most Canadians identify with and aspire to attain in education.

For Ontario policy-makers, this analysis would suggest the need to consider more seriously the importance of technology and the globalization of higher education, as these factors could radically alter and disrupt the competitive landscape by lowering barriers to entry and by increasing the availability of substitute products. This result could make for a much more competitive higher education landscape in Ontario, squeezing out profitability for higher education institutions, forcing the nature of competition to change, and creating niche players through differentiation. The policy question for Ontario is to what degree government wishes to influence these five forces, because the degree of support for or of opposition to these forces will guide the future competitiveness and marketization of the higher education industry in the province.

If, as Usher and Dunn (2009) suggest, government funding priorities do move away from education and toward health care, then universities will continue to face increasing pressure to increase revenues from non-traditional sources. As a result, Canadian/Ontarian universities will need to become better at modularizing knowledge and delivering it in locally appropriate forms through (international) educational partnerships. They further argue that this same scenario may force a 
re-evaluation of the delivery of higher education itself, perhaps resulting in the creation of a two-tier faculty, one committed to teaching and the other to research.

Alternatively, instead of reducing funding, the government may choose to pour more funds into higher education. Martin (2009) argues that "it will take an increased annual education expenditure of over $\$ 21$ billion across all levels of government in Canada to return to the per capita spending position we enjoyed relative to the US in 1995 .... Ontario, because it has allowed its spending gap with the States to grow even wider, would require $\$ 10$ billion, consuming nearly half of the $\$ 21$ billion even though only 39 percent of the Canadian population lives here" (p. 27). As Rae (2005) indicated, such support will require a financial commitment by government at both the provincial and federal levels. One of the key questions for the near future, then, is whether the government will do so. If not, it is likely that strong competition will have a considerable impact on the shape of the higher education industry in Ontario.

\section{REFERENCES}

Armstrong, L. (2006). Disruptive technologies: When great universities fail? Retrieved from http://www.changinghighereducation.com/2006/03/disruptive_ tech.html

Berger, J. (2009). Participation in post-secondary education: Recent trends. In J. Berger, A. Motte, \& A. Parki (Eds.), The Price of knowledge. Access and student finance in Canada (4th ed.). Montreal: The Canada Millennium Scholarship Foundation.

CBC News. (2009). Universities squabble over research funding. Retrieved from http:/ / www.cbc.ca/ canada/ calgary/story / 2009/08/26/ university-research-concentration-big-five.html

Christensen, C. (Ed.). (1997). The innovator's dilemma: When new technologies cause great firms to fail. Boston, MA: Harvard Business School Press.

Clark, B. R. (1983). The higher education system: Academic organisation in crossnational perspective. Berkeley, CA: University of California Press.

De Boer, H., Enders, J., \& Jongbloed, B. (2009). Market governance in higher education. In B. M. Kehm, J. Huisman, \& B. Stensaker (Eds.), The European higher education area: Perspectives on a moving target (pp. 61-78). Rotterdam: Sense.

Dill, D. (2003). Allowing the market to rule: The case of the United States. Higher Education Quarterly, 57(2), 136-157.

Duczmal, W. (2006). The rise of private higher education in Poland: Policies, markets and strategies. Enschede, the Netherlands: CHEPS.

Elloumi, F. (2004). Value chain analysis: A strategic approach to online learning. In T. Anderson \& F. Elloumi (Eds.), Theory and practice of online learning (pp. 61-92). Athabasca, AB: Creative Commons.

Fisher, D., Rubenson, K., Jones, G., \& Shanahan, T. (2009). The political economy of post-secondary education: A comparison of British Columbia, Ontario and Quebec. Higher Education, 57(5), 549-566. 
Holley, K. A., \& Taylor, B. J. (2009). Undergraduate student socialization and learning in an online professional curriculum. Innovative Higher Education, 33(4), 257-269.

Hood, C. (1998). The art of the state: Culture, rhetoric and public management. Oxford: Clarendon Press.

Hood, C., James, O., Peters, B. G., \& Scott, C. (Eds.). (2004). Controlling modern government: Variety, commonality and change. Cheltenham, UK, \& Northampton, MA: Edward Elgar.

Huisman, J., \& Currie, J. (2004). Accountability in higher education: Bridge over troubled water? Higher Education, 48, 529-551.

Huisman, J., De Weert, E., \& Bartelse, J. (2002). Academic careers from a European perspective. Journal of Higher Education, 73(1), 140-160.

Jones, G., Shanahan, T., \& Goyan, P. (2004). The academic senate and university governance in Canada. Canadian Journal of Higher Education, 34(2), 35-68.

Jongbloed, B. (2003). Marketisation in higher education, Clark's triangle and the essential ingredients of markets. Higher Education Quarterly, 57(2), 110-135.

Martin, R. (2009). Who killed Canada's education advantage? A forensic investigation into the disappearance of public education investment in Canada. Retrieved from http: / / www.walrusmagazine.com/articles/2009.11-policy-who-killed-canadaseducation-advantage/.

Martinez, M., \& Wolverton, M. (2009). Analyzing higher education as an industry. In M. Martinez \& M. Wolverton (Eds.), Innovative Strategy Making in Higher Education (pp. 45-62). Charlotte, NC: Information Age.

Mintzberg, H. (1994). The fall and rise of strategic planning. Harvard Business Review, 72(1), 107-114.

Naidoo, R. (2005). Universities in the marketplace: The distortion of teaching and research. In R. Barnett (Ed.), Reshaping the university: New relationships between research, scholarship and teaching (pp. 27-36). Berkshire, England: Open University Press.

Naidoo, R. (2008). Building or eroding intellectual capital? Student consumerism as a cultural force in the context of knowledge economy. In J. Valimmaa \& O.H. Ylijoki (Eds.), Cultural perspectives on higher education (pp. 43-55). Netherlands: Springer.

Olsen, J. P. (1988). Administrative reform and theories of organization. In C. Campbell \& B. G. Peters (Eds.), Organizing governance; governing organizations (pp. 233-254). Pittsburgh: University of Pittsburgh Press.

Porter, M. E. (1985). Competitive advantage: Creating and sustaining superior performance. New York: Free Press.

Porter, M. E. (2001). Strategy and the Internet. Harvard Business Review, 79(3), 16.

Porter, M. E. (2008). The five competitive forces that shape strategy. Harvard Business Review, 86(1), 79-93. 
Rae, B. (2005). Ontario: A leader in learning. Toronto: Government of Ontario.

U.S. Department of Education, Office of Planning, Evaluation, and Policy Development (2009). Evaluation of evidence-based practices in online learning: A metaanalysis and review of online learning studies. Washington, DC.

Usher, A., \& Dunn, R. (2009). On the brink-How the recession of 2009 will affect post-secondary education. Toronto: Educational Policy Institute.

van Vught, F. A. (1989). Government strategies and innovation in higher education. London: Jessica Kingsley.

Weingarten, H. P., \& Deller, F. (2010). The benefits of greater differentiation of Ontario's university sector-Final report. Toronto: Higher Education Quality Council of Ontario (HEQCO).

White, N. R. (2009). Tertiary education in the noughties: The student perspective. In M. Tight, K. H. Mok, J. Huisman, \& C. Morphew (Eds.), The Routledge international handbook of higher education (pp. 137-149). New York: Routledge.

\section{CONTACT INFORMATION}

James Pringle

School of Health Services Management

Ryerson University

350 Victoria Street

Toronto ON M5B 2K3 Canada

pringle@ryerson.ca

James Pringle was the past program manager, and is currently an instructor, at Ryerson's School of Health Services Management while enrolled as a doctoral student in the Higher Education Management program of the University of Bath's School of Management. In his role as program manager, he presented and published a paper on the use of simulations as an instructional tool and sat on two certification review panels for the Association for Undergraduate Programs in Health Administration (AUPHA). His current areas of research interest are higher education policy, strategic management in higher education, and branding and brand management in higher education.

Jeroen Huisman is Professor of Higher Education Management and Director of the International Centre for Higher Education Management (2005-present). He previously worked (1991-2005) as junior and senior researcher at the Center for Higher Education Policy Studies, University of Twente, the Netherlands. He holds an MSc in educational studies (1991, University of Groningen, the Netherlands) and a PhD in public administration (1995, University of Twente). His areas of research interest are higher education policy, internationalization, institutional governance, and organizational change in higher education. 